\title{
The use and limits of ITS data in the analysis of intraspecific variation in Passiflora L. (Passifloraceae)
}

\author{
Geraldo Mäder ${ }^{1}$, Priscilla M. Zamberlan ${ }^{1}$, Nelson J.R. Fagundes ${ }^{1}$, Tielli Magnus ${ }^{1}$, \\ Francisco M. Salzano ${ }^{1}$, Sandro L. Bonatto ${ }^{2}$ and Loreta B. Freitas ${ }^{1}$ \\ ${ }^{1}$ Programa de Pós-Graduação em Genética e Biologia Molecular, Departamento de Genética, \\ Instituto de Biociências, Universidade Federal do Rio Grande do Sul, Porto Alegre, RS, Brazil. \\ ${ }^{2}$ Laboratório de Biologia Genômica e Molecular, Faculdade de Biociências, \\ Pontifícia Universidade Católica do Rio Grande do Sul, Porto Alegre, RS, Brazil.
}

\begin{abstract}
The discovery and characterization of informative intraspecific genetic markers is fundamental for evolutionary and conservation genetics studies. Here, we used nuclear ribosomal ITS sequences to access intraspecific genetic diversity in 23 species of the genus Passiflora L. Some degree of variation was detected in 21 of these. The Passiflora and Decaloba (DC.) Rchb. subgenera showed significant differences in the sizes of the two ITS regions and in GC content, which can be related to reproductive characteristics of species in these subgenera. Furthermore, clear geographical patterns in the spatial distribution of sequence types were identified in six species. The results indicate that ITS may be a useful tool for the evaluation of intraspecific genetic variation in Passiflora.
\end{abstract}

Key words: genetic diversity, intraspecific variability, ITS, Passiflora, phylogeography.

Received: March 11, 2009; Accepted: July 14, 2009.

\section{Introduction}

Understanding the distribution of alleles throughout the geographic range of a species is fundamental for molecular evolutionists, allowing inferences about the influence of historical processes in the spatial distribution of particular lineages (Emerson et al., 2001). Phylogeography is a young discipline that represents a bridge linking population genetics, molecular phylogenetics and biogeography, amongst other fields (Avise et al., 1987; Avise, 2000). Phylogenetic methods can be used to construct haplotype trees that would indicate the historical relationships of gene lineages in a population or species. By comparing such trees to the geographical structure of the data one can infer historical patterns of population subdivision, as well as come to an understanding of current distribution of the major genetic clusters in a studied species, which may be useful for conservation purposes (Frankham et al., 2002). Furthermore, well-resolved phylogenies at the specieslevel or below are necessary to identify the taxa and populations which have undergone recent speciation and those which are currently diverging (Bradshaw et al., 1995; Whittall et al., 2006).

Send correspondence to Loreta B. Freitas. Departamento de Genética, Instituto de Biociências, Universidade Federal do Rio Grande do Sul, Caixa Postal 15053, 91501-970 Porto Alegre, RS, Brazil. E-mail: loreta.freitas@ufrgs.br.
For over two decades, nuclear ribosomal ITS (internal transcribed spacers of the large subunit of ribosomal DNA) has been the most popular molecular marker in the nuclear genome for evolutionary studies in various plant groups (e.g. Baldwin et al., 1995; Alvarez and Wendel, 2003; Hughes et al., 2006; Nieto-Feliner and Rosselló, 2007). Even though the use of ITS as a molecular marker might be problematic because of paralogy and other complex evolutionary patterns caused by its highly repetitive nature (Alvarez and Wendel, 2003), the general evolutionary mechanism for this region proposes that most intragenomic copies would share identical sequences as a result of concerted evolution, a homogenizing process that depends on unequal crossing over during meiosis and biased gene conversion (Dover, 1994; Liao, 1999).

Another advantage in using ITS as molecular marker in plants is that it provides an alternative to cpDNA markers, which may inform only part of the history of a species, since cpDNA is usually inherited from only one of the parents (Birky Jr., 2001; Xu, 2005), and thus proposed migration patterns based entirely on cpDNA may be inaccurate when applied to the population as a whole. The ITS region has been successfully used to infer phylogeographic patterns in a wide range of species (Jeandroz et al. 1997; Manos et al., 1999; Rodriguez-Lanetty and Hoegh-Guldberg, 2002; Duran et al., 2004; Lorenz-Lemke et al., 2005; Koehler-Santos et al., 2006; Nettel and Dodd, 2007; 
Yamaji et al., 2007). Furthermore, since the ITS region is flanked by well-conserved rRNA genes, universal primers can be used for widely different plant groups, thereby avoiding the need for developing specific primer sets, as is the case for SSR markers.

Passiflora L. is the largest genus in the Passifloraceae, consisting of over 520 species, recently split into four subgenera (Feuillet and MacDougal, 2003). The molecular phylogeny of the genus has been investigated by various authors, and in general is in agreement with the morphological proposition of subgenera classification (Muschner et al., 2003; Yockteng and Nadot, 2004; Hansen et al., 2006). Particularly, Muschner et al. (2003) and AK Hansen (PhD. Thesis, University of Texas, 2004) have used ITS to estimate phylogenies for the whole genus. Krosnick and Freudenstein (2005) have used ITS with success to analyze Supersection Disemma (subgenus Decaloba (DC.) Rchb. Lorenz-Lemke et al. (2005) and Koehler-Santos et al. (2006) have also assessed intraspecific variability for two Passiflora species based on ITS sequences.

In this study, we used ITS sequences to evaluate general patterns of intra and interspecific variation in several species representing all four Passiflora subgenera, to test the usefulness of this genetic marker for further phylogeographic studies in this genus. We found general differences in ITS structure between the two most speciose subgenera (Passiflora and Decaloba), besides identifying geographic associations among lineages in at least six species.

\section{Materials and Methods}

\section{Plant material and DNA extraction}

Leaf material was obtained from different geographical regions (Table 1). Figure 1 shows collection sites for those species whose preliminary phylogeographical pattern

Table 1 - List of the species studied, their taxonomic position according to the infrageneric classification of Feuillet and MacDougal (2003), and GenBank accession numbers for DNA sequences. The number of individuals examined, the number of collection sites and the geographic origin of the populations are given for each species.

\begin{tabular}{|c|c|c|c|c|c|c|}
\hline Subgenus & Species & $\mathrm{N}$ & Collection sites $^{\mathrm{a}}$ & Geographic regions ${ }^{\mathrm{b}}$ & Sequence types ${ }^{c}$ & Genbank \\
\hline \multirow[t]{13}{*}{ Passiflora } & P. amethystina & 3 & 3 & $\mathrm{RS}, \mathrm{SC}, \mathrm{SP}$ & 3 & EU258307 - EU258309 \\
\hline & P. caerulea & 24 & 14 & RS & 4 & EU258310 - EU258313 \\
\hline & P. cinccinata & 7 & 6 & MS, MG, BA, PE & 7 & EU258352 - EU258358 \\
\hline & P. edmundoi & 5 & 4 & BA, MG, RJ & 5 & EU258370 - EU258374 \\
\hline & P. edulis & 12 & 8 & $\mathrm{RS}, \mathrm{SC}, \mathrm{MG}$ & 10 & EU258375 - EU258384 \\
\hline & P. eichleriana & 7 & 4 & $\mathrm{RS}, \mathrm{SC}$ & 3 & EU258317 - EU258319 \\
\hline & P. foetida & 9 & 6 & RS, SC, PE, PB & 7 & $\begin{array}{l}\text { EU258386 - EU258391; } \\
\text { EU258394 }\end{array}$ \\
\hline & P. jilekii & 5 & 4 & $\mathrm{SC}$ & 1 & EU258320 \\
\hline & P. miersii & 3 & 1 & SP & 1 & EU258322 \\
\hline & P. sidaefolia & 12 & 2 & SP, MG & 1 & EU258435 \\
\hline & P. tenuifila & 15 & 2 & $\mathrm{RS}$ & 8 & EU258446 - EU258453 \\
\hline & P. urubiciensis & 12 & 11 & $\mathrm{RS}, \mathrm{SC}$ & 1 & EU258326 \\
\hline & P. villosa & 6 & 5 & SC, PR, SP, MG & 6 & $\begin{array}{l}\text { EU258392 - EU258393; } \\
\text { EU258466 - EU258469 }\end{array}$ \\
\hline \multirow[t]{7}{*}{ Decaloba } & P. capsularis & 42 & 5 & RS, SC, PR, SP, MG & 19 & EU258327 - EU258345 \\
\hline & P. misera & 15 & 5 & $\mathrm{RS}$ & 4 & EU258409 - EU258412 \\
\hline & P. morifolia & 7 & 5 & RS, SP & 2 & EU258323 - EU258324 \\
\hline & P. organensis & 17 & 9 & RS, SC, PR, MG & 13 & EU258414 - EU258426 \\
\hline & P. pohlii & 5 & 4 & MG, MS & 1 & EU258325 \\
\hline & P. tricuspis & 8 & 4 & SP, MS, DF & 6 & EU258455 - EU258460 \\
\hline & P. urnaefolia & 9 & 4 & RS, SP, MG & 4 & EU258462 - EU258465 \\
\hline \multirow[t]{2}{*}{ Astrophea } & P. haematostigma & 19 & 6 & $\mathrm{SC}, \mathrm{PR}, \mathrm{SP}, \mathrm{MG}$ & 9 & EU258395 - EU258403 \\
\hline & P. rhamnifolia & 12 & 5 & MG & 6 & $\begin{array}{l}\text { EU258427 - EU258429; } \\
\text { EU258432 - EU258434 }\end{array}$ \\
\hline Deidamioides & P. ovalis & 18 & 7 & ES, BA & 11 & EU258359 - EU258369 \\
\hline
\end{tabular}

${ }^{a}$ The collection sites for $P$. cinccinata P. organensis and P. haematostigma are shown in Figure 1.

${ }^{\mathrm{b}}$ Abbreviations refer to Brazilian states: RS: Rio Grande do Sul; SC: Santa Catarina; PR: Paraná; SP: São Paulo; RJ: Rio de Janeiro; ES: Espírito Santo; MG: Minas Gerais; MS: Mato Grosso do Sul; DF: Distrito Federal; BA: Bahia; PE: Pernambuco.

${ }^{\mathrm{c}}$ Sequence types found for the whole region (ITS1 + 5.8S + ITS2). 


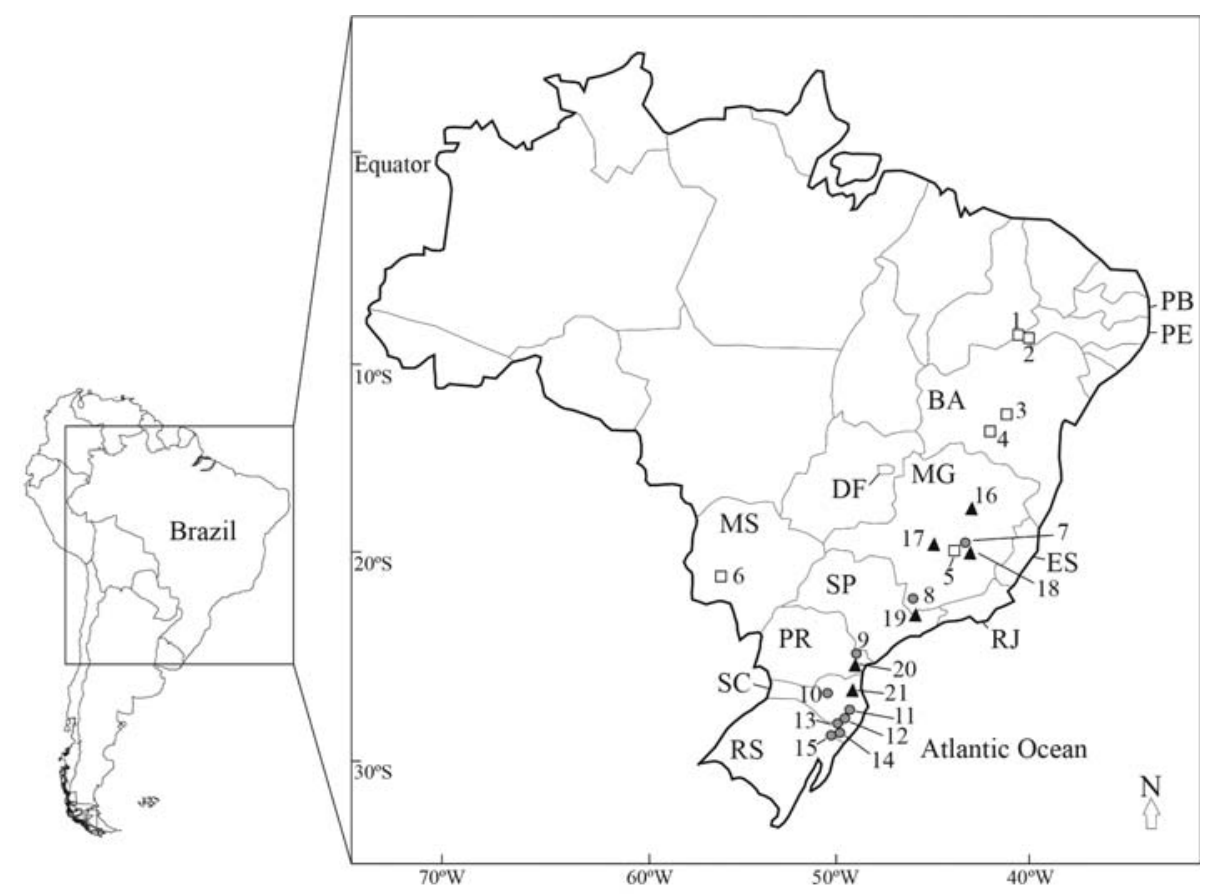

Figure 1 - Map of Brazil indicating the origin of samples of the three Passiflora species whose preliminary phylogeographical patterns were evaluated. Squares - P. cincinnata, circles - P. organensis, and triangles - P. haematostigma.

was evaluated. Voucher specimens were deposited in the ICN Herbarium, Botany Department, Biosciences Institute, Federal University of Rio Grande do Sul. Total DNA was extracted from young leaves dried in silica gel, using the method of Roy et al. (1992).

\section{PCR amplification and sequencing}

Internal transcribed spacers (ITS 1 and 2) were amplified using primers and amplification conditions as described by Desfeux and Lejeune (1996). To exclude the presence of low stability templates, $10 \%$ dimethyl sulfoxide (DMSO) was used (Buckler IV et al., 1997; Fuertes-Aguilar et al., 1999). PCR products were checked by horizontal electrophoresis in 1\% agarose gel stained with GelRed (Biotium). All PCR products were purified using the polyethyleneglycol (PEG) precipitation method (Dunn and Blattner, 1987). The sequencing reaction was performed as described by Sanger et al. (1977) using ET terminators kit (GE Healthcare) on a MegaBACE 1000 automatic sequencer (Amersham Biosciences). The quality of the sequences was examined through the Chromas package (available from http://www.technelysium.com.au/ chromas.html). Nucleotide sequences were searched against the GenBank database (http://ncbi.nlm.nih.gov/ BLAST) using BLAST tools (Altschul et al., 1990).

\section{Data analysis}

GenBank numbers for the obtained sequences are given in Table 1. Forward and reverse reads were analyzed for all sequences. A site was identified as ambiguous when double peaks occurred in the same position in both strands, with the weakest signal reaching at least $25 \%$ of the strength of the strongest (Fuertes-Aguilar et al., 1999; Fuertes-Aguilar and Nieto-Feliner, 2003). The term 'ambiguous' was used instead of 'heterozygote site', as the origin of ambiguity could not be determined with any degree of certainty, since a variation might represent an actual heterozygote (for which each allele had been inherited from one parent) or only a variation among different ITS copies across the genome. Thus, in all analysis, ambiguous sites were treated as missing data. Sequences were aligned with the PRANK program (Löytynoja and Goldman, 2008). Variable sites, nucleotide and haplotypic diversity, were estimated using the Arlequin 3.11 (Excoffier et al., 2005) software. Relationships among sequences were inferred by means of median-joining networks (Bandelt et al., 1999) under Network version 4.5. Finally, inter and intraspecific distances were estimated with PAUP* version 4.0 (Swofford, 1998), by taking the distance estimated through maximum likelihood, and assuming the evolutionary model suggested under the Aikaike Information Criterion in the Modeltest 3.7 program (Posada and Crandall, 1998). Since the sequences among subgenera were too divergent to be combined in the same alignment, diversity in each subgenus was analyzed separately.

\section{Results}

GC content ranged from $49 \%$ to $66 \%$ (Table 2 - alignments are available directly from the authors), with an average of $60 \%$, being significantly higher in the subgenus 


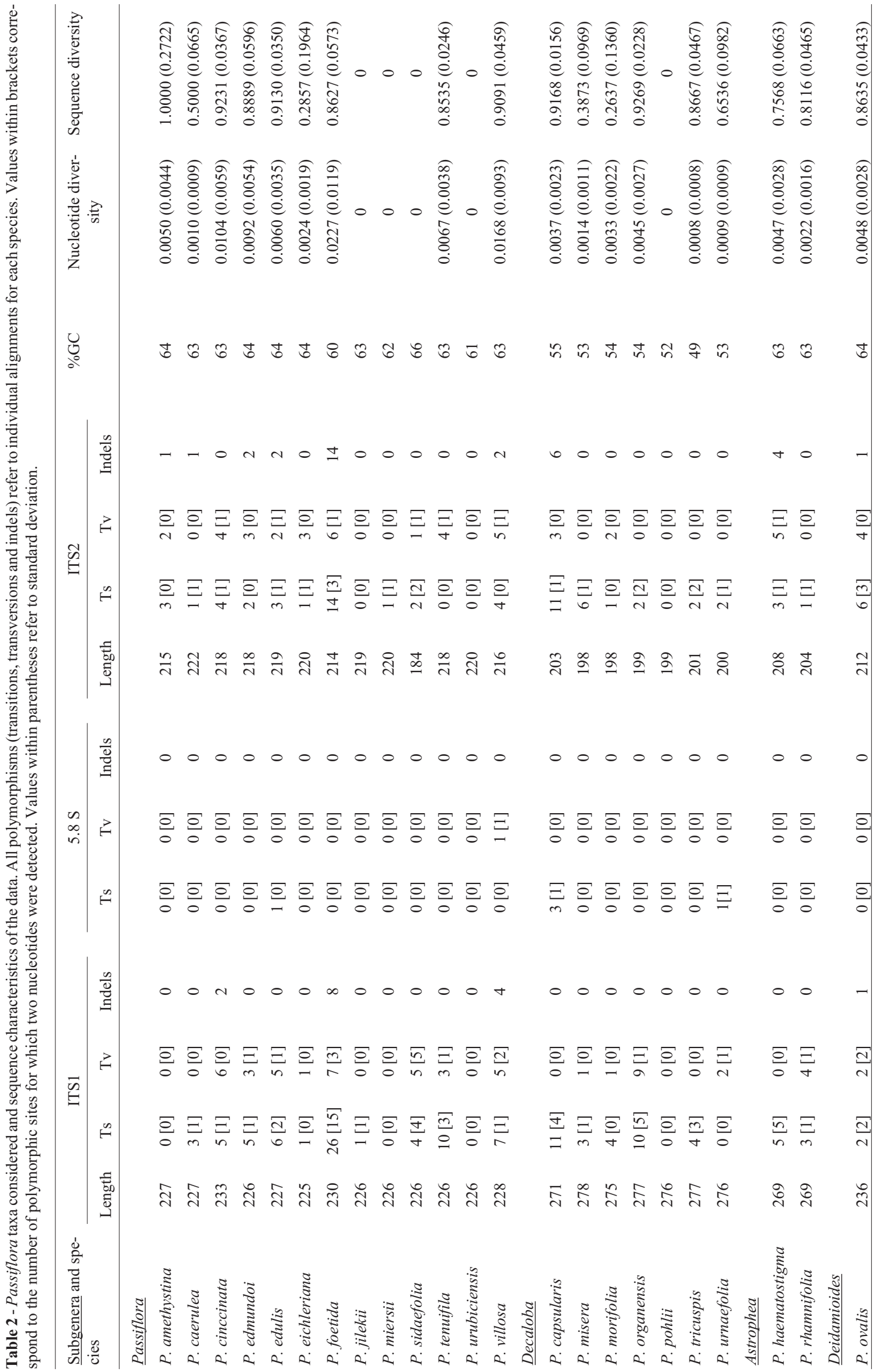


Passiflora (63\%) than in Decaloba $(53 \%)(\mathrm{p}<0.002)$. ITS1 length varied between $225 \mathrm{bp}$ ( $P$. eichleriana Mast.) and $278 \mathrm{bp}$ ( $P$. misera HBK), whereas for ITS2, this variation was from $184 \mathrm{bp}$ ( $P$. sidaefolia M. Roemer) to $222 \mathrm{bp}(P$. caerulea L.) (Table 2). ITS length was significantly different between the two subgenera for both ITS1 and ITS2 (Table 3$)$. The size of the $5.8 \mathrm{~S}$ gene ( $160 \mathrm{bp}$ ) was constant in all analyzed species, although a certain intraspecific polymorphism, half of which represented by ambiguous sites, was found in this region in P. capsularis L., P. edulis Sims., $P$. urnaefolia Rusby. and $P$. villosa Vell.

With the exception of $P$. pohlii Mast., in Mart. (subgenus Decaloba) and P. urubiciensis Cervi (subgenus Passiflora), both of which were monomorphic, all species had some degree of intraspecific variability, represented by insertion/deletion (indels) and substitution events, part of which involving ambiguities. When we excluded all ambiguities from the dataset for subsequent analyses we found that three more species become monomorphic $(P$. jilekii Wawra, $P$. miersii Mast. in Mart. and P. sidaefolia, all belonging to the subgenus Passiflora). The number of nucleotide substitutions was higher than indels, and transitions more numerous than transversions (Table 2). The intraspecific index of nucleotide diversity varied from zero to 0.0227 (Table 2). The highest intraspecific pairwise distance was 0.0447 ( $P$. foetida L.). Pairwise interspecific distances between individuals belonging to species from the same subgenus, varied from 0.0128 to 0.0260 in the subgenus Astrophea (DC.) Mast. (both between $P$. haematostigma Mart. ex Mast. and P. rhamnifolia Mast.), from 0.0049 (P. tricuspis Mast. in Mart. vs. P. organensis Gard.) to 0.3860 ( $P$. capsularis vs. P. morifolia Mast. in Mart.) in Decaloba and from zero (P. miersii Mast. in Mart. vs. P. edmundoi Sacco) to 0.1713 ( $P$. caerulea vs. P. foetida) in Passiflora. For the subgenus Deidamioides (Harms) Killip a single species was studied. The distributions of inter and intraspecific pairwise distances are shown in Figure 2.

As in this study we presented an overview of ITS genetic diversity in Passiflora species as a whole, rather than an exhaustive analysis of just a few species, it could be argued that the somewhat limited, and to some extent, unequal sampling of the different species may tend to bias our estimates. To assess the influence of sample size on genetic

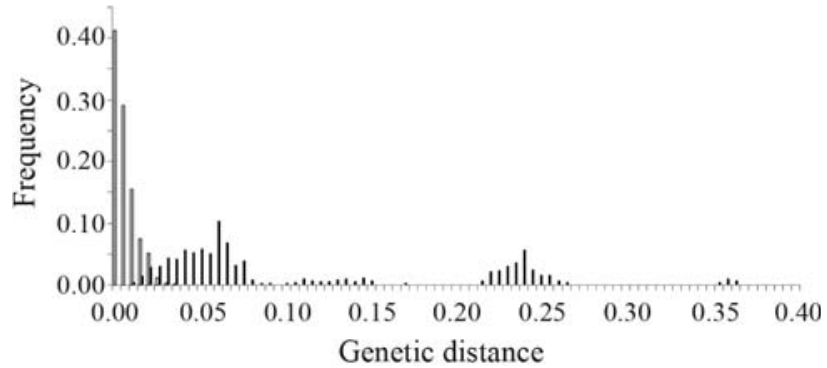

Figure 2 - Histogram showing the distribution of frequency values of intra (empty bars) and interspecific (solid bars) genetic distances. Interspecific genetic distances were calculated only comparing species belonging to the same subgenus.

diversity, we calculated the Spearman correlation coefficient between either sample size or number of sampled populations against two measures of genetic diversity, the number of different sequence types and nucleotide diversity. We observed a significant positive correlation between sample size and both the number of sampled populations and that of different sequence types $(\mathrm{rS}=0.601$, $\mathrm{p}=0.002$ and $\mathrm{rS}=0.462, \mathrm{p}=0.027$, respectively). Nevertheless, when nucleotide diversity was considered, no significant correlation was found with either sample size or the number of sampled localities $(\mathrm{rS}=0.070, \mathrm{p}=0.751$; and $\mathrm{rS}=0.260, \mathrm{p}=0.231$; respectively). These results indicate that the values presented here for nucleotide diversity are independent of sampling artifacts, and thus may be viewed as approximations of the level of genetic diversity in these species. However, it is also evident from our data that increased sampling would be required for a better characterization of all sequence types present in a given species.

When considered together with sampling locations, genetic variation for at least six species $(P$. haematostigma, $P$. organensis, $P$. cincinnata Mast., $P$. edmundoi, $P$. villosa, and P. capsularis) showed some geographic structure as can be observed from the network connecting the different sequence types (Table 4; Figure 3). For $P$. cincinnata (Figure 3a) there was a central core of sequence types located in NE Brazil (BA and PE states), to which the others were connected, the most distantly located population also having the most divergent sequence type. A more complex picture was observed for $P$. organensis (Figure $3 \mathrm{~b}$ ), wherein the most distinct lin-

Table 3 - Passiflora subgenera average characteristics. Values within parentheses refer to the range of variation or standard deviation.

\begin{tabular}{lccccccc}
\hline Subgenus & Species number & \% GC & ITS1 length & ITS2 length & $\begin{array}{c}\text { Ambiguous sites } \\
\text { number }\end{array}$ & $\begin{array}{c}\text { Nucleotide } \\
\text { diversity }\end{array}$ & $\begin{array}{c}\text { Sequence } \\
\text { diversity }\end{array}$ \\
\hline Passiflora & 13 & $63^{*}(60-66)$ & $227^{*}(225-233)$ & $216^{*}(184-222)$ & $4(0-22)$ & $0.0062(0.0036)$ & $0.5489(0.0611)$ \\
Decaloba & 7 & $53^{*}(49-54)$ & $276^{*}(271-278)$ & $200^{*}(198-203)$ & $3(0-8)$ & $0.0021(0.0014)$ & $0.5736(0.0595)$ \\
Astrophea & 2 & 63 & 269 & $206(204-208)$ & $5(3-7)$ & $0.0035(0.0022)$ & $0.7842(0.0564)$ \\
Deidamioides & 1 & 64 & 236 & 212 & 7 & $0.0048(0.0028)$ & $0.8635(0.0433)$ \\
\hline
\end{tabular}

*Statistically significant values $(\mathrm{p}<0.002)$. 
Table 4 - Collection points of Passiflora species considered in phylogeographic analyses.

\begin{tabular}{|c|c|c|c|}
\hline Species & Sampling sites & Geographic coordinates & Sequence types \\
\hline \multirow[t]{6}{*}{ P. cincinnata } & 1- Casa Nova/BA & $09^{\circ} 09^{\prime} 43^{\prime \prime} \mathrm{S} / 40^{\circ} 58^{\prime} 15^{\prime \prime} \mathrm{W}$ & c2 \\
\hline & 2- Petrolina/PE & $09^{\circ} 23^{\prime} 55^{\prime \prime} \mathrm{S} / 40^{\circ} 30^{\prime} 03^{\prime \prime} \mathrm{W}$ & $\mathrm{c} 1$ \\
\hline & 3- Abaíra/BA & $13^{\circ} 14^{\prime} 59^{\prime \prime} \mathrm{S} / 41^{\circ} 39^{\prime} 49^{\prime \prime} \mathrm{W}$ & $\mathrm{c} 3, \mathrm{c} 4$ \\
\hline & 4- Caetité/BA & $14^{\circ} 07^{\prime} 36^{\prime \prime} \mathrm{S} / 42^{\circ} 26^{\prime} 05^{\prime \prime} \mathrm{W}$ & c3 \\
\hline & 5- Brumadinho/MG & $20^{\circ} 08^{\prime} 36^{\prime \prime} \mathrm{S} / 44^{\circ} 11^{\prime} 59^{\prime \prime} \mathrm{W}$ & c7 \\
\hline & 6- Jardim/MS & $21^{\circ} 28^{\prime} 49^{\prime \prime} \mathrm{S} / 56^{\circ} 07^{\prime} 53^{\prime \prime} \mathrm{W}$ & c6 \\
\hline \multirow[t]{9}{*}{ P. organensis } & 7- Caeté/MG & $19^{\circ} 52^{\prime} 56^{\prime \prime} \mathrm{S} / 43^{\circ} 40^{\prime} 12^{\prime \prime} \mathrm{W}$ & 03 \\
\hline & 8- Munhoz/MG & $22^{\circ} 36^{\prime} 31^{\prime \prime} \mathrm{S} / 46^{\circ} 21^{\prime} 41^{\prime \prime} \mathrm{W}$ & o1, o2 \\
\hline & 9- Quatro Barras/PR & $25^{\circ} 20^{\prime} 16^{\prime \prime} \mathrm{S} / 48^{\circ} 54^{\prime} 49^{\prime \prime} \mathrm{W}$ & $\mathrm{o} 4, \mathrm{o} 5, \mathrm{o} 6$ \\
\hline & 10- Petrolândia/SC & $27^{\circ} 35^{\prime} 29^{\prime \prime} \mathrm{S} / 49^{\circ} 44^{\prime} 14^{\prime \prime} \mathrm{W}$ & $05,08,09$ \\
\hline & 11-Bom Jardim da Serra/SC & $28^{\circ} 22^{\prime} 14^{\prime \prime} \mathrm{S} / 49^{\circ} 34^{\prime} 41^{\prime \prime} \mathrm{W}$ & 08 \\
\hline & 12- Timbé do Sul/SC & $28^{\circ} 49^{\prime} 42^{\prime \prime} \mathrm{S} / 49^{\circ} 50^{\prime} 30^{\prime \prime} \mathrm{W}$ & 08 \\
\hline & 13- Praia Grande/SC & $29^{\circ} 07^{\prime} 25^{\prime \prime} \mathrm{S} / 49^{\circ} 58^{\prime} 29^{\prime \prime} \mathrm{W}$ & 07 \\
\hline & 14- Três Cachoeiras/RS & $29^{\circ} 26^{\prime} 53^{\prime \prime} \mathrm{S} / 49^{\circ} 55^{\prime} 37^{\prime \prime} \mathrm{W}$ & $\mathrm{o} 10$ \\
\hline & 15- Maquiné/RS & $29^{\circ} 34^{\prime} 36^{\prime \prime} \mathrm{S} / 50^{\circ} 17^{\prime} 35^{\prime \prime} \mathrm{W}$ & o11, o12, o13 \\
\hline \multirow[t]{6}{*}{ P. haematostigma } & 16- São Gonçalo do Rio Preto/MG & $18^{\circ} 00^{\prime} 15^{\prime \prime} \mathrm{S} / 43^{\circ} 23^{\prime} 27^{\prime \prime} \mathrm{W}$ & $\mathrm{h} 2, \mathrm{~h} 4$ \\
\hline & 17- Araújos/MG & $19^{\circ} 53^{\prime} 59^{\prime \prime} \mathrm{S} / 45^{\circ} 15^{\prime} 21^{\prime \prime} \mathrm{W}$ & $\mathrm{h} 2$ \\
\hline & 18- Itabirito/MG & $20^{\circ} 22^{\prime} 01^{\prime \prime} \mathrm{S} / 43^{\circ} 39^{\prime} 40^{\prime \prime} \mathrm{W}$ & $\mathrm{h} 1, \mathrm{~h} 2, \mathrm{~h} 3, \mathrm{~h} 4$ \\
\hline & 19- Biritiba/SP & $23^{\circ} 39^{\prime} 04^{\prime \prime} \mathrm{S} / 46^{\circ} 08^{\prime} 17^{\prime \prime} \mathrm{W}$ & h5, h6, h7 \\
\hline & 20- Guaratuba/PR & $25^{\circ} 52^{\prime} 58^{\prime \prime} \mathrm{S} / 48^{\circ} 34^{\prime} 29^{\prime \prime} \mathrm{W}$ & h9 \\
\hline & 21- Rancho Queimado/SC & $27^{\circ} 40^{\prime} 59^{\prime \prime} \mathrm{S} / 49^{\circ} 01^{\prime} 59^{\prime \prime} \mathrm{W}$ & h8, h9 \\
\hline
\end{tabular}

a)

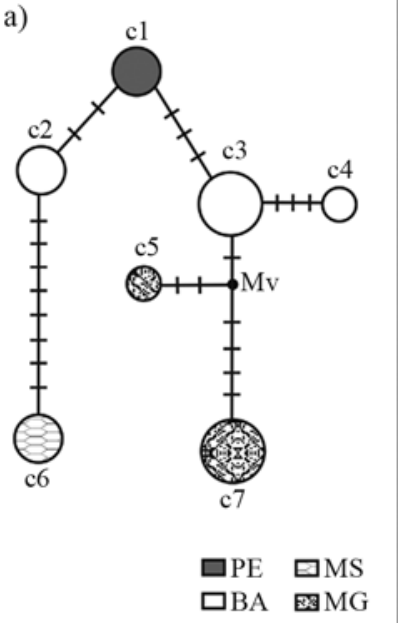

b)

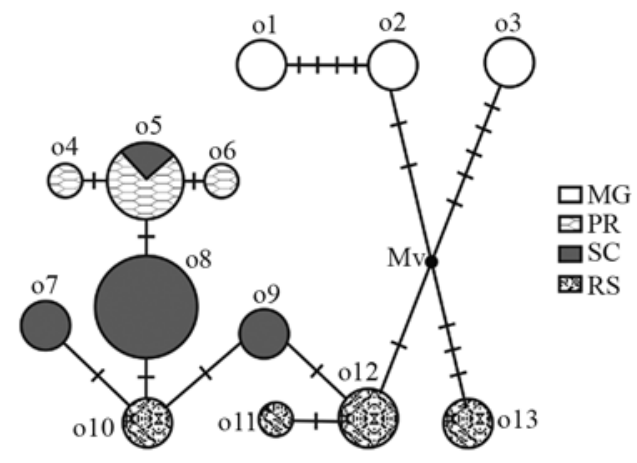

c)

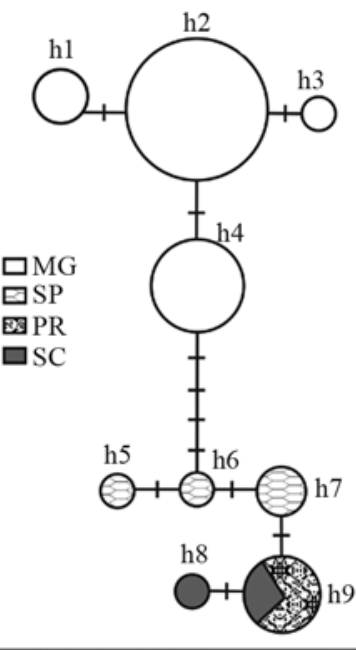

Figure 3 - Median-joining networks based on ITS sequence types. Each circle represents a sequence type, their sizes being proportional to respective frequencies. Shading indicates the state in Brazil where each sequence-type was found (according to boxes; key to the abbreviations in Table 4). Transversal bars indicate the number of mutations that differentiate sequence types; Mv: median vector. The differences between the numbers of sequence types indicated in Table 1 for $P$. haematostigma are due to hypervariable sites that were removed for network analysis. $3 \mathrm{a}-P$. cincinnata $; 3 \mathrm{~b}-P$. organensis; $3 \mathrm{c}-P$. haematostigma. The relationship between sequence types and collection sites is indicated in Table 4 .

eages were found at the two extremes of distribution (MG and RS, see Figure1), whereas another group of lineages was arranged in a roughly north/south gradient. A clearer pattern emerged for $P$. haematostigma (Figure 3c), with a clear separation between the sequences from Minas Ge- rais $(\mathrm{MG})$ and those from other more southern localities, which are arranged in a north/south gradient (SP, PR, SC). Finally, in the three remaining species we also found differences among isolated individuals from different re- 
gions albeit with a non-trivial relationship between genetic lineages and geography.

\section{Discussion}

In almost all the species sampled in this study ( 21 out of 23), a certain degree of genetic variation occurred in the ITS region, even though for some of these only few individuals were sequenced. This is in agreement with other studies, thereby implying that in Passiflora, the ITS region seems to be more informative at the populational level than other marker. Lorenz-Lemke et al. (2005), when studying 32 individuals of $P$. actinia Hook and 20 individuals of $P$. elegans Mast., and Koehler-Santos et al. (2006), studying 32 plants from $P$. alata Curtis, all discovered genetic variation on using ITS but none with cpDNA markers. LorenzLemke et al. (2005) found 32 polymorphic sites. Nucleotide diversity was 0.0060 in P. actinia and 0.0020 in $P$. elegans, whereas Koehler-Santos et al. (2006) detected an ITS nucleotide diversity value of 0.0036 as in P. alata.

Patterns of intraspecific variation in Passiflora have been also studied by using different markers. More specifically, Fajardo et al. (1998) employed RAPD markers and found higher levels of variation in $P$. ligularis Juss. and $P$. adenopoda DC. when compared to $P$. edulis and $P$. maliformis L., whereas Sanchez et al. (1999) used cpDNA restriction fragment length polymorphism, and found intraspecific variation in four species ( $P$. maliformis, $P$. ligularis, $P$. edulis, and P. mollissima (Kunth) Bailey), but no variation in another three ( $P$. caerulea, $P$. sp. india, and P. adenopoda). Finally, a morphometric approach undertaken by Plotze et al. (2005) found different levels of variation in leaf vein pattern among ten species, with $P$. caerulea being the most diverse. Even though differences among sampled species and markers make a direct comparison of these studies difficult, the emerging overall picture is that intraspecific variation is not evenly distributed among species, and that a common pattern of intraspecific diversity for the nuclear genome, the plastid genome and morphology may be hard to obtain, given the discrepancy of different datasets for the same species (e.g. P. caerulea, P. edulis and $P$. maliformis). Possibly, this picture reflects the complexities of the evolutionary history of the genus, and indicates that robust patterns would only emerge when different markers are considered together.

In this study we did not take into consideration sites for which two nucleotides could be detected in the same individual. Because there are several ITS repeats and because each individual inherited its genome from both of its parents, it is not possible to know whether sites harboring two different nucleotides are really heterozygous or whether they rather represent ITS sequence variation across different repeats in a single haploid genome. It is therefore impossible to infer meaningful haplotypes based on ITS sequences obtained from PCR amplifications from total DNA. Importantly, because we excluded from our analysis all sites with ambiguous information, the degree of genetic variation in the ITS region in this genus is actually an underestimate. A way of maximizing the detection of genetic variation in ITS sequences would be by cloning all individuals and sequencing multiple clones for each. However, this alternative is not only expensive for phylogeographic and population genetics studies, but might also be subject to criticism because one would be mixing orthologous and paralogous variation in a single analysis (Bailey et al., 2003). AK Hansen (PhD. Thesis, University of Texas, 2004) sequenced ITS clones obtained for 41 Passiflora species and observed that in $25 \%$ of the studied taxa, various ITS sequences were more related to sequence types in other species. It is not known whether this illustrates the complexity of using paralogue ITS sequences in a single analysis or not, since, according to other studies on the same genus, variation patterns inconsistent with sequence types from a single monophyletic species have never been found (Muschner et al., 2003; Krosnick and Freudenstein, 2005; Lorenz-Lemke et al., 2005).

A comparison of intra and interspecific genetic distances (Figure 2) suggests little overlap between the two levels, with more than $50 \%$ of the intraspecific comparisons resulting in values larger than zero, thus stressing the potential of the ITS region as a molecular marker in phylogeographic studies in Passiflora. The narrow overlap between intra and interspecific values may be understood in two-ways. First, the intraspecific genetic variation may be inflated if there are unrecognized species within a given taxon name. This may be the case for P. foetida, for which 38 varieties are recognized (Killip, 1938), and which showed the highest intraspecific variation (Table 2). A thorough taxonomic revision of this species would therefore considerably reduce the overlap between intra and interspecific genetic variation in the ITS region. Second, interspecific distances are expected to be low between recently diverged species. Thus, we may expect that either recent speciation events or taxonomic confusion would cause an overlap between genetic distances estimated at these two taxonomic levels. This may be of special concern for speciose groups. Moreover, differences represented by indel events are not taken into account when estimating distances, thus probably reducing the overall estimate of interspecific divergence. For example, some individuals from $P$. miersii and $P$. edmundoi are only differentiated by a 2-bp indel in the ITS2 region.

Provided that concerted evolution is often invoked as an explanation for the maintenance of genetic homogeneity among ITS copies, why then does genetic variation in the ITS region seems to be the rule rather than the exception in Passiflora species? The time for homogenizing different ITS copies depends on the number of the different copies, on the number of different chromosomes containing nrDNA, and on the crossing-over rate among chromosomes (Quijada et al., 1998), since crossing-over towards telo- 
meres seems to be more common, as previously shown in Gossypium L. and Thinopyrum A. Löve (Wendel et al., 1995; Li and Zhang, 2002). Melo and Guerra (2003) mapped the $45 \mathrm{~S}$ ribosomal DNA (including the ITS region) in several Passiflora species. In none of the species analyzed (including $P$. capsularis, $P$. cincinnata, $P$. edulis, $P$. haematostigma and $P$. morifolia, had nrDNA located in telomeres, this indicating that chromosome location in this genus may be, at least partly, responsible for a slow down in the homogenization of the different ITS copies. This could partially explain, independent of the taxonomy issues, the high values observed for $P$. foetida, which has six nrDNA clusters far from telomeres, in regions of reduced crossing-over.

The differences in ITS1 and ITS2 length and GC content, detected among species in the subgenera Passiflora and Decaloba, might be related to their significantly different evolutionary rates, as shown by Muschner et al. (2003). The latter also ascertained that ITS1 and ITS2 nucleotide diversities were significantly higher in Decaloba than in Passiflora species. Decaloba species are in general selfcompatible (Ulmer and MacDougal, 2004), a condition that favors lower intrapopulation and higher interpopulation genetic diversities, as there is less pollen dispersion (Maki et al., 1999). In the present work, no difference was detected when average intraspecific nucleotidic diversities were compared in Passiflora. This indicates that, despite the different evolutive rates, ITS intraspecific variability it is not distinct in these subgenera. We consider that the differentiated evolutionary rates in the subgenera Decaloba and Passiflora do not represent obstacles to the use of ITS markers for intraspecific populational analysis in Passiflora species. However, this question must be handled carefully when dealing with phylogenetic questions in this genus and is worthy of future study.

Even though our study did not aim at detecting fine phylogeographic structure for these species, for at least six species, sampling site location could be related to the observed genetic diversity. Despite the low number of samples, the overall pattern seems to indicate a general latitudinal trend. Of course, detailed phylogeographic studies will be required to reveal accurate geographic patterns, and to infer those evolutionary processes that influenced the distribution of the genetic lineages currently found in these species. It is interesting to note that Lorenz-Lemke et al. (2005), also based on ITS sequences, detected similar patterns in P. actinia and P. elegans. Palynological data indicate two Holocene expansions in the Brazilian Atlantic Rain Forest from the northeast towards south Brazil (Lorscheitter, 1997). Nonetheless, any extensive assessment of whether the history of the genetic lineages within these species indeed reflects concordant colonization routes in the Brazilian Atlantic Rain Forest will await further studies and additional data.
Despite their complex evolution, ITS sequences have high inter and intraspecific variability in Passiflora species. This information can be of importance for accessing their evolutionary history and contributing to conservation. At least in some species, a clear geographic structure of sequence types can be identified, with expressive agreement among the different species. As a whole, the results presented here indicate that ITS is a useful tool for evaluating intraspecific variability in Passiflora species.

\section{Acknowledgments}

To Cladinara Roberts Sarturi for aid with sequencing. This project was supported by Conselho Nacional de Desenvolvimento Científico e Tecnológico (CNPq), Coordenação de Aperfeiçoamento de Pessoal de Nível Superior (CAPES), Programa Especial em Taxonomia (CNPq-PROTAX), Fundação de Amparo à Pesquisa do Estado do Rio Grande do Sul (FAPERGS), and Pró-Reitoria de Pesquisa da Universidade Federal do Rio Grande do Sul (PROPESQ-UFRGS).

\section{References}

Altschul SF, Gish W, Miller W, Myers EW and Lipman DJ (1990) Basic local alignment search tool. J Mol Biol 215:403-410.

Alvarez I and Wendel JF (2003) Ribosomal ITS sequences and plant phylogenetic inference. Mol Phylogenet Evol 29:417434.

Avise JC (2000) Phylogeography: The History and Formation of Species. Harvard University Press, London, 447 pp.

Avise JC, Arnold J, Ball RM, Bermingham E, Lamb T, Neigel JE, Reeb CA and Saunders NC (1987) Intraspecific phylogeography: The mitochondrial DNA bridge between population genetics and systematics. Annu Rev Ecol Syst 18:489-522.

Bailey CD, Carr TG, Harris SA and Hughes CE (2003) Characterization of angiosperm nrDNA polymorphism, paralogy and pseudogenes. Mol Phylogenet Evol 29:435-455.

Baldwin BG, Sanderson MJ, Porter JM, Wojciechowski MF, Campbell CS and Donoghue MJ (1995) The ITS region of nuclear ribosomal DNA: A valuable source of evidence on Angiosperm phylogeny. Ann Mo Bot Gard 82:247-277.

Bandelt HJ, Forster P and Röhl A (1999) Median-joining networks for inferring intraspecific phylogenies. Mol Biol Evol 16:37-48.

Birky Jr. CW (2001) The inheritance of genes in mitochondria and chloroplasts: Laws, mechanisms, and models. Annu Rev Genet 35:125-148.

Bradshaw HD, Wilbert SM, Otto KG and Schemske DW (1995) Genetic mapping of floral traits associated with reproductive isolation in monkey flowers (Mimulus). Nature 376:762765.

Buckler IV ES, Ippolito A and Holtsford TP (1997) The evolution of ribosomal DNA: Divergent paralogues and phylogenetic implications. Genetics 145:821-832.

Desfeux C and Lejeune B (1996) Systematics of Euromediterranean Silene (Caryophyllaceae): Evidence from a phylogenetic analysis using ITS sequence. C R Acad Sci Paris 319:351-358. 
Dover G (1994) Concerted evolution, molecular drive and natural selection. Curr Biol 4:1165-1166.

Dunn IS and Blattner FR (1987) Charons 36 to 40: Multi-enzyme, high capacity, recombination deficient replacement vectors with polylinkers and polystuffers. Nucleic Acids Res 15:2677-2698.

Duran S, Giribet G and Turon X (2004) Phylogeographical history of the sponge Crambe crambe (Porifera, Poecilosclerida): Range expansion and recent invasion of the Macaronesian islands from the Mediterranean Sea. Mol Ecol 13:109-122.

Emerson BC, Paradis E and Thebaud C (2001) Revealing demographic histories of species using DNA sequence data. Trends Ecol Evol 16:707-716.

Excoffier L, Laval G and Schneider S (2005) Arlequin v. 3.0: An integrated software package for population genetics data analysis. Evol Bioinform online 1:47-50.

Fajardo D, Angel F, Grum M, Tohme J, Lobo M, Roca WM and Sanchez I (1998) Genetic variation analysis of the genus Passiflora L. using RAPD markers. Euphytica 101:341-347.

Feuillet CP and MacDougal JM (2003) A new infrageneric classification of Passiflora. Passiflora 13:34-38.

Frankham R, Ballaou JD and Briscoe DA (2002) Introduction to Conservation Genetics. Cambridge University Press, Cambridge, $642 \mathrm{pp}$.

Fuertes-Aguilar J and Nieto-Feliner G (2003) Additive polymorphisms and reticulation in an ITS phylogeny of thrifts (Armeria, Plumbaginaceae). Mol Phylogenet Evol 28:430447.

Fuertes-Aguilar J, Rosselló JA and Nieto-Feliner G (1999) Nuclear ribosomal DNA (nrDNA) concerted evolution in natural and artificial hybrids of Armeria (Plumbaginaceae). Mol Ecol 8:1341-1346.

Hansen AK, Gilbert LE, Simpson BB, Downie SR, Cervi AC and Jansen RK (2006) Phylogenetic relationships and chromosome number evolution in Passiflora. Syst Bot 31:138-150.

Hughes CE, Eastwood RJ and Bailey CD (2006) From famine to feast? Selecting nuclear DNA sequence loci for plant species-level phylogeny reconstruction. Phil Trans R Soc B 361:211-225

Jeandroz S, Roy A and Bousquet J (1997) Phylogeny and phylogeography of the circumpolar genus Fraxinus (Oleaceae) based on internal transcribed spacer sequences of nuclear ribosomal DNA. Mol Phylogenet Evol 7:241-251.

Killip EP (1938) The American species on Passifloraceae. Field Mus Nat Hist Bot Ser 19:1-613.

Koehler-Santos P, Lorenz-Lemke AP, Muschner VC, Bonatto SL, Salzano FM and Freitas LB (2006) Molecular genetic variation in Passiflora alata (Passifloraceae), an invasive species in southern Brazil. Biol J Linn Soc Lond 88:611-630.

Krosnick SE and Freudenstein JV (2005) Monophyly and floral character homology of Old World Passiflora (Subgenus Decaloba, Supersection Disemma). Syst Bot 30:139-152.

Li D and Zhang X (2002) Physical localization of the 18S$5.8 \mathrm{~S}-26 \mathrm{~S}$ rDNA and sequence analysis of ITS regions in Thinopyrum ponticum (Poaceae, Triticaceae): Implications for concerted evolution. Ann Bot 90:445-452.

Liao D (1999) Concerted evolution: Molecular mechanism and biological implications. Am J Hum Genet 64:24-30.

Lorenz-Lemke AP, Muschner VC, Bonatto SL, Cervi AC, Salzano FM and Freitas LB (2005) Phylogeographic inferences concerning evolution of Brazilian Passiflora actinia and $P$. elegans (Passifloraceae) based on ITS (nr DNA) variation. Ann Bot 95:799-806.

Lorscheitter ML (1997) Paleoambientes do sul do Brasil no Quaternário através da palinologia: Revisão dos resultados obtidos. Rev Univ Guarulhos - Geociênc 2:197-199 (Abstract in English).

Löytynoja A and Goldman N (2008) Phylogeny-aware gap placement prevents errors in sequence alignment and evolutionary analysis. Science 320:1632-1635.

Maki M, Morita H, Oiki S and Takahashi H (1999) The effect of geographic range and dichogamy of genetic variability and population genetic structure in Tricyrtis section Flavae (Liliaceae). Am J Bot 86:287-292.

Manos PS, Doyle JJ and Nixon KC (1999) Phylogeny, biogeography, and processes of molecular differentiation in Quercus subgenus Quercus (Fagaceae). Mol Phylogenet Evol 12:333-49.

Melo NF and Guerra Filho MS (2003) Variability of the 5S and 45S rDNA sites in Passiflora L. species with distinct base chromosome numbers. Ann Bot 92:309-316.

Muschner VC, Lorenz AP, Cervi AC, Bonatto SL, Souza-Chies TT, Salzano FM and Freitas LB (2003) A first molecular phylogenetic analysis of Passiflora (Passifloraceae). Am J Bot 90:1229-1238.

Nettel A and Dodd RS (2007) Drifting propagules and receding swamps: Genetic footprints of mangrove recolonization and dispersal along tropical coasts. Int J Org Evol 61:958-71.

Nieto-Feliner G and Rosselló JA (2007) Better the devil you know? Guidelines for insightful utilization of nrDNA ITS in species-level evolutionary studies in plants. Mol Phylogenet Evol 44:911-919.

Plotze RO, Falvo M, Pádua JG, Bernacci LC, Vieira MLC, Oliveira GCX and Bruno OM (2005) Leaf shape analysis using the mutiscale Minkowski fractal dimension, a new morphometric method: A study with Passiflora (Passifloraceae) Can J Bot 83:287-301.

Posada D and Crandall KA (1998) Modeltest: Testing the model of DNA substitution. Bioinformatics 14:817-818.

Quijada A, Liston A, Delgado P, Vázquez-Lobo A and Alvarez-Buylla ER (1998) Variation in the nuclear ribosomal DNA internal transcribed spacer (ITS) region of Pinus rzedowskii revealed by PCR-RFLP. Theor Appl Genet 96:539-544.

Rodriguez-Lanetty M and Hoegh-Guldberg O (2002) The phylogeography and connectivity of the latitudinally widespread scleractinian coral Plesiastrea versipora in the Western Pacific. Mol Ecol 11:1177-1189.

Roy A, Frascaria N, Mackay J and Bousquet J (1992) Segregating random amplified polymorphic DNAs (RAPDs) in Betula alleghaniensis. Theor Appl Genet 85:173-180.

Sánchez I, Angel F, Grum M, Duque MC, Lobo M, Tohme J and Roca W (1999) Variability of chloroplast DNA in the genus Passiflora L. Euphytica 106:15-26.

Sanger F, Nicklen S and Coulson AR (1977) DNA sequencing with chain-terminating inhibitors. Proc Natl Acad Sci USA 74:5463-5467.

Swofford DL (1998) PAUP* Phylogenetic Analysis Using Parsimony (* and others methods) v. 4. Sinauer Associates, Sunderland. 
Ulmer T and MacDougal JM (2004) Passiflora: Passionflowers of the world. Timber Press, Portland, 430 pp.

Wendel JF, Schnabel A and Seelanan T (1995) Bidirectional interlocus concerted evolution following allopolyploid speciation in cotton (Gossypium). Proc Natl Acad Sci USA 92:280-284.

Whittall JB, Medina-Marino A, Zimmer EA and Hodges SA (2006) Generating single-copy nuclear gene data for a recent adaptive radiation. Mol Phylogenet Evol 39:124-34.

$\mathrm{Xu}$ J (2005) The inheritance of organelle genes and genomes: Patterns and mechanisms. Genome 48:951-958.

Yamaji H, Fukuda T, Yokoyama J, Pak J-H, Zhou C-Z, Yang C-S, Kondo K, Morota T, Takeda S, Sasaki H, et al. (2007) Retic- ulate evolution and phylogeography in Asarum sect. Asiasarum (Aristolochiaceae) documented in internal transcribed spacer sequences (ITS) of nuclear ribosomal DNA. Mol Phylogenet Evol 44:863-884.

Yockteng R and Nadot S (2004) Phylogenetic relationships among Passiflora species base on the glutamine synthetase nuclear gene expressed in chloroplast (ncpGS). Mol Phylogenet Evol 31:379-396.

Associate Editor: Márcio de Castro Silva Filho

License information: This is an open-access article distributed under the terms of the Creative Commons Attribution License, which permits unrestricted use, distribution, and reproduction in any medium, provided the original work is properly cited. 